\title{
Fostering improved human islet research: a European perspective
}

\author{
Piero Marchetti ${ }^{1}$ - Anke M. Schulte ${ }^{2} \cdot$ Lorella Marselli $^{1} \cdot$ Eyke Schoniger ${ }^{3} \cdot$ Marco Bugliani $^{1} \cdot$ Werner Kramer $^{2}$. \\ Lut Overbergh ${ }^{4}$. Susanne Ullrich ${ }^{5}$. Anna L. Gloyn ${ }^{6,7,8}$. Mark Ibberson ${ }^{9}$. Guy Rutter ${ }^{10}$. Philippe Froguel ${ }^{11}$. \\ Leif Groop ${ }^{12}$ - Mark I. McCarthy ${ }^{6,7,8} \cdot$ Francesco Dotta $^{13,14} \cdot$ Raphael Scharfmann $^{15} \cdot$ Christophe Magnan $^{16}$. \\ Decio L. Eizirik ${ }^{17} \cdot$ Chantal Mathieu $^{4} \cdot$ Miriam Cnop $^{17,18} \cdot$ Bernard Thorens $^{19} \cdot$ Michele Solimena $^{3}$
}

Received: 10 April 2019 / Accepted: 24 April 2019 / Published online: 13 June 2019

(C) The Author(s) 2019

Keywords Beta cells $\cdot$ Diabetes research $\cdot$ Human islets

Abbreviations
IMIDIA

Innovative Medicines Initiative for Diabetes: improving beta-cell function and identification of diagnostic biomarkers for treatment monitoring in diabetes

INNODIA Translational approaches to disease modifying therapy of type 1 diabetes: An innovative approach towards understanding and arresting Type 1 diabetes

LCM Laser capture microdissection

Piero Marchetti

piero.marchetti@med.unipi.it

1 Department of Clinical and Experimental Medicine, Cisanello University Hospital, via Paradisa 2, 56126 Pisa, Italy

2 Sanofi-Aventis Deutschland GmbH, Diabetes Research, Industriepark Höchst, Frankfurt am Main, Germany

3 Paul Langerhans Institute Dresden of the Helmholtz Center Munich at University Hospital Carl Gustav Carus and Faculty of Medicine, Dresden, Germany

4 Clinical and Experimental Endocrinology, University Hospital Gasthuisberg, Leuven, Belgium

5 Institute for Diabetes Research and Metabolic Diseases of the Helmholtz Center Munich at the Eberhard Karls University of Tübingen, Tübingen, Germany

6 Oxford Centre for Diabetes Endocrinology and Metabolism, University of Oxford, Oxford, UK

7 Wellcome Centre for Human Genetics, University of Oxford, Oxford, UK

8 NIHR Oxford Biomedical Research Centre, Churchill Hospital, Oxford, UK

9 Vital-IT Group, SIB Swiss Institute of Bioinformatics, Lausanne, Switzerland
RHAPSODY Assessing risk and progression of prediabetes and type 2 diabetes to enable disease modification

T2DSystems Development of a systems biomedicine approach for risk identification, prevention and treatment of type 2 diabetes

To the Editor: We read with much interest the review article by Hart and Powers, recently published in Diabetologia, on the

10 Section of Cell Biology and Functional Genomics, Division of Diabetes, Endocrinology and Metabolism, Imperial College, London, UK

11 Department of Genomics of Common Disease, School of Public Health, Imperial College, London, UK

12 Department of Clinical Sciences, Faculty of Medicine, Lund University, Malmö, Sweden

13 Department of Medicine, Surgery and Neuroscience, University of Siena, Siena, Italy

14 Fondazione Umberto di Mario ONLUS -Toscana Life Sciences, Siena, Italy

15 INSERM, Cochin Institute, Paris Descartes University, Paris, France

16 Unité de Biologie Fonctionnelle et Adaptative, Université Paris Diderot, Paris, France

17 ULB Center for Diabetes Research, Medical Faculty, Université Libre de Bruxelles, Brussels, Belgium

18 Division of Endocrinology, ULB Erasmus Hospital, Université Libre de Bruxelles, Brussels, Belgium

19 Centre for Integrative Genomics, University of Lausanne, Lausanne, Switzerland 
progress and challenges of the use of human islets in the understanding of islet cell biology and diabetes [1]. In the initial sections of the article, the authors highlight the advances in several areas of human islet cell biology, made possible by the increased availability of islets for research purposes, isolated from the pancreases of organ donors $[2,3]$. Such areas include islet architecture, beta cell function and turnover, molecular phenotypes and comparisons with rodent islets. These sections mainly focus on islets from non-diabetic donors, and pay limited attention, if any, to the progress achieved by the use of isolated islets obtained from diabetic individuals. In fact, over the past 10-15 years, several studies have contributed to the identification of islet changes associated with type 1 and, in particular, type 2 diabetes. Although space limitations do not allow a comprehensive listing of all the major advances in this field, we think it is important to summarise at least some key achievements and important differences between 'type 2 diabetic' and 'non-diabetic' islets (Table 1). They comprise islet morphology and ultrastructure, changes in beta cell identity, insulin secretion defects in response to selective secretagogues (particularly glucose), possible beta cell rescue, mechanisms of islet cell death, the role of genetic and epigenetic factors, gene and protein expression patterns and the search for biomarkers of sick beta cells [4-12]. Taking into consideration the differences between healthy and diseased islet cells is key to elucidating the trajectory of beta cell failure during early glucose intolerance, diabetes onset and disease progression, in order to eventually conceive targeted strategies for the prevention, better treatment and possible remission of this disease.

In the second part of their review, Hart and Powers underline how the characteristics of the islets used in a large proportion of the available studies are inconsistently and marginally reported, making comparisons among studies difficult and scarcely reliable [1]. Hence, the authors propose a list of actions to be put in place, including a record of standardised information on the islets studied, to guarantee more sound and reproducible results. We endorse this request and, certainly, the ongoing discussion will help us to move towards a balance between the need for characterisation and the feasibility of this [13]. Over the past few years, a number of projects on islet pathophysiology have been funded by the European Union, also, in some cases, with the support of the European Federation of Pharmaceutical Industries and Associations (EFPIA), JDRF and charitable trusts (such as the Leona M. and Harry B. Helmsley Charitable Trust). These projects are IMIDIA (Innovative Medicines Initiative for Diabetes: improving beta-cell function and identification of diagnostic biomarkers for treatment monitoring in diabetes, www.imidia.org), T2DSystems (Development of a systems biomedicine approach for risk identification, prevention and treatment of type 2 diabetes, www.t2dsystems.eu), RHAPSODY (Assessing risk and progression of prediabetes and type 2 diabetes to enable disease modification, www.imi-rhapsody.eu) and INNODIA (Translational approaches to disease modifying therapy of type 1 diabetes: An innovative approach towards understanding and arresting Type 1 diabetes, www.innodia.eu). The key participating islet isolating centres have been scrupulously preparing and characterising their human islet preparations (currently more than 400) according to rigorous standardised procedures. The information to be reported on the donors' clinical characteristics and isolated islet features will be further implemented to comply with the emerging requirements $[1,13]$. Importantly, the biorepositories of isolated islets generated in these projects include several well-characterised samples obtained from organ donors with type 2 diabetes, and these are being used to shed further light on the pathophysiology of islet cells in diabetes.

As reported by Hart and Powers [1], the vast majority of studies on human islet cells have employed islets isolated from the pancreas of organ donors. The advantages of this model include the use of transplantation-grade procedures to yield large amounts of islets that can be evaluated in terms of composition, function, survival and molecular properties under different experimental conditions. IMIDIA and RHAPSODY, on the other hand, also introduced the standardised collection and analysis of islet samples obtained following pancreatic surgery from nondiabetic people, individuals with varying degrees of glucose intolerance, and people with recent-onset diabetes or long-
Table 1 Differences in key features of islets isolated from type 2 diabetic vs non-diabetic organ donors

\begin{tabular}{lll}
\hline Feature & T2D vs ND islets & Reference \\
\hline Beta cell identity & $\begin{array}{l}\text { Increased number of de-differentiated beta cells, which correlates } \\
\text { with the reduction of glucose-stimulated insulin release }\end{array}$ & {$[4]$} \\
Insulin secretory function & $\begin{array}{c}\text { Reduced insulin release in response to acute glucose challenge, } \\
\text { associated with lower glucose oxidation } \\
\end{array}$ & {$[5,6]$} \\
& $\begin{array}{l}\text { Reduced insulin granule exocytosis associated with T2D gene } \\
\text { variants }\end{array}$ & \\
Beta cell turnover & $\begin{array}{l}\text { Increased apoptosis, endoplasmic reticulum stress and islet } \\
\text { cell inflammation }\end{array}$ & {$[7]$} \\
Possible beta cell rescue & $\begin{array}{l}\text { Improved insulin secretion from T2D islets after culture } \\
\text { Epigenetics } \\
\text { Gene expression }\end{array}$ & {$[8]$} \\
\hline
\end{tabular}

ND, non-diabetic; T2D, type 2 diabetic 
standing type 2 diabetes [4]. This has allowed the study of the molecular features of islet cells yielded by laser capture microdissection (LCM) [3, 12], as well as morphometric analysis and study of islet function in fresh tissue slices [14]. One obvious advantage of this approach is that individuals can be metabolically investigated before surgery and, if required, after recovery from the operation. In RHAPSODY, the reliability of this approach has been corroborated by comparing the transcriptome of LCM islets from two cohorts of surgical patients collected at different research sites and according to the same stringent protocols [15] and through the identification of the largest subset of islet expression quantitative trait loci (QTLs) to date [16]. Standardisation of the use of this model in different centres will further contribute to the advancement of human islet research.

Funding This manuscript is based on work performed with the support of non-profit organizations and public bodies for funding of scientific research conducted within the European Union: Innovative Medicines Initiative Joint Undertaking under grant agreeement no. 155005 (IMIDIA), which received financial contributions from the European Union's Seventh Framework Program (FP7/2007-2013) and companies belonging to the European Federation of Pharmaceutical Industries and Associations (EFPIA); Innovative Medicines Initiative 2 Joint Undertaking under grant agreements number 115881 (RHAPSODY) and number 115797 (INNODIA), which include financial contributions from European Union's Seventh Framework Programme (FP7/2007-2013) and Horizon 2020 research and innovation programme, EFPIA, JDRF, the Leona M. and Harry B. Helmsley Charitable Trust, and the Swiss State Secretariat for Education, Research and Innovation (SERI) under contract number 16.0097; the European Union's Horizon 2020 research and innovation programme, project T2DSystems, under grant agreement number 667191. ALG is a Wellcome Trust Senior Fellow in Basic Biomedical Science. This work was funded in Oxford by the Wellcome Trust (095101 [ALG], 200837 [ALG], 098381 [MIM], 106130 [ALG, MIM], 203141 [MIM]), Medical Research Council (MR/L020149/1 [MIM, ALG]), and NIH (U01-DK105535; U01-DK085545 [MIM, ALG]). The research was funded by the National Institute for Health Research (NIHR) Oxford Biomedical Research Centre (BRC) (ALG, MIM). The views expressed are those of the author(s) and not necessarily those of the NHS, the NIHR or the Department of Health.

Duality of interest AMS and WK are employees of Sanofi-Aventis. GR has received research grants from Servier and is consultant for Sun Pharmaceuticals. MIMcC has received research grants from Pfizer, Merck, NovoNordisk, Abbvie, Sanofi-Aventis, Servier, Takeda, Eli Lilly, AstraZeneca, Boehringer Ingelheim, Janssen and Roche; is consultant for Pfizer, NovoNordisk, Zoe Global, Merck and Eli Lilly; has received honorarium from Pfizer and Merck; is share-holder of Zoe Global. The remaining authors declare that there is no duality of interest associated with this manuscript.

Contribution statement All authors were responsible for drafting the article and revising it critically for important intellectual content. All authors approved the version to be published.

Open Access This article is distributed under the terms of the Creative Commons Attribution 4.0 International License (http:// creativecommons.org/licenses/by/4.0/), which permits unrestricted use, distribution, and reproduction in any medium, provided you give appropriate credit to the original author(s) and the source, provide a link to the Creative Commons license, and indicate if changes were made.

\section{References}

1. Hart NJ, Powers AC (2019) Use of human islets to understand islet biology and diabetes: progress, challenges and suggestions. Diabetologia 62(2):212-222. https://doi.org/10.1007/s00125-0184772-2

2. Kaddis JS, Olack BJ, Sowinski J, Cravens J, Contreras JL, Niland JC (2009) Human pancreatic islets and diabetes research. JAMA 301(15):1580-1587. https://doi.org/10.1001/jama.2009.482

3. Marchetti P, Suleiman M, Marselli L (2018) Organ donor pancreases for the study of human islet cell histology and pathophysiology: a precious and valuable resource. Diabetologia 61(4): 770-774. https://doi.org/10.1007/s00125-018-4546-x

4. Cinti F, Bouchi R, Kim-Muller JY et al (2016) Evidence of $\beta$-cell de-differentiation in human type 2 diabetes. J Clin Endocrinol Metab 101(3):1044-1054. https://doi.org/10.1210/jc.2015-2860

5. Del Guerra S, Lupi R, Marselli L et al (2005) Functional and molecular defects of pancreatic islets in human type 2 diabetes. Diabetes 54(3):727-735. https://doi.org/10.2337/diabetes.54.3.727

6. Rosengren AH, Braun M, Mahdi T et al (2012) Reduced insulin exocytosis in human pancreatic $\beta$-cells with gene variants linked to type 2 diabetes. Diabetes 61(7):1726-1733. https://doi.org/10. 2337/db11-1516

7. Eizirik DL, Cardozo AK, Cnop M (2008) The role for endoplasmic reticulum stress in diabetes mellitus. Endocr Rev 29(1):42-61. https://doi.org/10.1210/er.2007-0015

8. Marchetti P, Del Guerra S, Marselli L et al (2004) Pancreatic islets from type 2 diabetic patients have functional defects and increased apoptosis that are ameliorated by metformin. J Clin Endocrinol Metab 89(11):5535-5541. https://doi.org/10.1210/jc.2004-0150

9. Volkmar M, Dedeurwaerder S, Cunha DA et al (2012) DNA methylation profiling identifies epigenetic dysregulation in pancreatic islets from type 2 diabetic patients. EMBO J 31(6):1405-1426. https://doi.org/10.1038/emboj.2011.503

10. Volkov P, Bacos K, Ofori JK et al (2017) Whole-genome bisulfite sequencing of human pancreatic islets reveals novel differentially methylated regions in type 2 diabetes pathogenesis. Diabetes 66(4): 1074-1085. https://doi.org/10.2337/db16-0996

11. Fadista J, Vikman P, Laakso EO et al (2014) Global genomic and transcriptomic analysis of human pancreatic islets reveals novel genes influencing glucose metabolism. Proc Natl Acad Sci U S A 111(38):13924-13929. https://doi.org/10.1073/pnas.1402665111

12. Solimena M, Schulte AM, Marselli L et al (2018) Systems biology of the IMIDIA biobank from organ donors and pancreatectomised patients defines a novel transcriptomic signature of islets from individuals with type 2 diabetes. Diabetologia 61(3):641-657. https:// doi.org/10.1007/s00125-017-4500-3

13. Poitout V, Satin LS, Kahn SE et al (2019) A call for improved reporting of human islet characteristics in research articles. Diabetologia 62(2): 209-211. https://doi.org/10.1007/s00125-018-4784-y

14. Marciniak A, Cohrs CM, Tsata V et al (2014) Using pancreas tissue slices for in situ studies of islet of Langerhans and acinar cell biology. Nat Protoc 9(12):2809-2822. https://doi.org/10.1038/nprot.2014.195

15. Gerst F, Jaghutriz BA, Staiger H et al (2018) The expression of aldolase B in islets is negatively associated with insulin secretion in humans. J Clin Endocrinol Metab 103(12):4373-4383. https:// doi.org/10.1210/jc.2018-00791

16. Khamis A, Canouil M, Siddiq A et al (2019) Laser capture microdissection of human pancreatic islets reveals novel eQTLs associated with type 2 diabetes. https://doi.org/10.1016/j.molmet.2019. 03.004

Publisher's note Springer Nature remains neutral with regard to jurisdictional claims in published maps and institutional affiliations. 